\title{
ORGANIZATION OF NATURE PROTECTION SYSTEM AND THE QUALITY OF MANAGEMENT IN NATIONAL PARKS - CONTRIBUTION TO THE DISCUSSION
}

Lyubomir Bezruchko, Assistant Prof. (ORCID: 0000-0003-0075-8631) - Ivan Franko National University of Lviv, Ukraine

Tomasz Pasierbek, MSc (ORCID: 0000-0003-0741-6351) - The University College of Tourism and Ecology, Poland

Rakos Juraj, MSc (ORCID: 0000-0001-7124-5732) - The University College of Tourism and Ecology, Poland

Yuriy Zhuk, BEng, MSc (ORCID: 0000-0002-1332-9863) - Ivan Franko National University of Lviv, Ukraine

Correspondence address:

Zamkowa 1,34-200 Sucha Beskidzka, Poland

e-mail: szkola@wste.edu.pl

ABSTRACT: The aim of the article is to compare the legal and administrative foundations of the functioning of national parks as factors determining the quality of management. National parks in Poland and Ukraine, representing different nature protection systems, were selected for the comparative analysis and evaluation. The data was obtained from published sources. The most important were legislations that create the legal basis of the nature protection systems in both countries. The available data were used for analysis using the Desk Research method. There are numerous differences between the Polish and Ukrainian systems of protected areas, mostly based upon the position in the government structure (what is the way of creating the national park and which ministry is responsible for it). Despite those differences, general conclusions can be drawn. Due to the separate legal entity of individual units, as well as subordination to various ministries, there is no clear link between the institutions. This hinders the flow of information and reporting and complicates the decision-making process both at individual units and between national parks.

KEYWORDS: national park, nature protection system, organisational structure, quality of management, decision-making process 


\section{Introduction}

Nature is a value in itself. Even though this maxim appears to be self-evident, the modern man appears to forget it all too often. The accelerating pace of life, still clearly visible consumption attitudes, conviction of eternal right ascribed to man to use goods - all this results in the growing expectation of satisfying human needs at the expense of environmental values. Fortunately, the tendency to make unhindered use of natural resources without paying attention to the imbalance of the environment is contrasted by the tendency to acknowledge the value of nature as a common good that should be respected, protected and cared for. It is by no means a new concept - this type of conviction has been with mankind basically since the beginning of time. For centuries, the protection of natural resources has been based on purely pragmatic reasons - from the human point of view, of course. We are talking here about reasons of religious origin (natural phenomena were treated as supernatural elements, sacred symbols of gods or places of worship), social (the most valuable and rich in game forest complexes or the most dignified animals were treated as the exclusive domain of kings or magnates) or military (such as protection of yew, which was the basic raw material for the production of bows). It took another century to recognise that nature deserves to be protected for its own sake and not because of its usefulness to man. The efforts of many generations of naturalists were crowned with success in 1872, when the world's first national park was established - Yellowstone National Park in the United States. Not much water flowed in the Vistula or the Dnieper, and the idea of creating protected areas was firmly established also in Central Europe.

In 1885, the idea of protecting the Tatra Mountains as the property of the whole nation emerged. Unfortunately, there was still a long way to go from the idea to its realisation. The first national parks were established in Poland in 1932 - these were the Pieniny National Park and Bialowieza National Park. The Tatra Mountains, which had been called for protection since the 1880s, had to wait for their national park until after the Second World War, more precisely until 1954. The oldest national park in Ukraine is the Carpathian National Park, which was established in 1980, but this does not mean that the protection of nature on the Dnieper River is only in the last 40 years. Much earlier, in 1898, Baron F. Falz-Fein announced the creation of the private park Askania-Nova, which was proclaimed a national park in 1919. This site is the first nature reserve in Ukraine.

The issue of national parks is a broad topic and may be the subject of extremely interesting research. This is due to the specific dualism of the 
national park: on the one hand, it is a form of nature protection (in this matter, natural aspects prevail); on the other hand, it is an institution and an employer that is bound by certain management standards. The specific place of national parks in the legal and administrative system (especially in terms of supervision over them, sources of financing and structural connections between individual parks) generates clear effects on the effectiveness of the management. It is not so visible if one looks only from one country's perspective, and thus one system of nature protection. It is much easier to see the advantages and disadvantages of a given system when compared with the systems in force in other countries. Analyses should begin with an assessment of the current state; in other words, it is necessary to answer the question of what the current situation of national parks looks like on both sides of the Polish-Ukrainian border. This comparison seems to be of great importance not only in theoretical but also in practical terms. It should be noted that in both countries, the structure of territorial forms of nature protection, especially administrative location and functioning of national parks, is different. It seems to be legitimated to assume that the Polish system, where responsibility lies on a single ministry, is clearer, despite its obvious drawbacks. The most important disadvantage, which needs to be corrected, is the lack of formal relationships between national parks within both systems. It is also important that, in contrast to Poland, in Ukraine, the dynamics of creating national parks are still noticeable. The question is if this situation results from differences in the system of protected areas, different management or just political decisions.

The analysis of the present situation of national parks in Ukraine and Poland should begin with a synthetic summary of the most important data concerning protected areas in both countries. Currently, there are 23 national parks on the territory of Poland, covering a total area of approx. 3,168 sq. km, which means that Poland's highest form of nature protection covers approx. $1 \%$ of the country's area. The smallest of the Polish national parks is the Ojców National Park, located in the Małopolskie Province, with $21.46 \mathrm{~km}^{2}$, while the largest is the Biebrza National Park, protecting $592.23 \mathrm{~km}^{2}$ in the Podlaskie Province.

Ukraine, in turn, currently has 53 areas designated as National Nature Parks. Their total area is just over $13276 \mathrm{~km}^{2}$, which is about $2.2 \%$ of the country's area. The largest national park is Podil Tovtry National Nature Park, with an area of $2316.16 \mathrm{~km}^{2}$ located in Khmelnytskyi Oblast, while the smallest is Derman-Ostroh National Nature Park, with an area of $16.48 \mathrm{~km}^{2}$, located in Rivne Oblast. 
The process of creating new national parks in Ukraine is underway. In 2019, 4 new national parks were created in Ukraine, and in 2020, 1 national park, while in Poland, the last national park was created in 2001.

\section{Materials and methods}

In order to obtain a broad perspective enabling the comparison of the functioning systems of national parks in Poland and Ukraine, research was carried out using the Desk Research analysis method. The data was obtained from available published sources, with the fundamental contribution made by analysing legal acts relating to nature protection, which function in the legal system in Poland and Ukraine. The international composition of the research team guaranteed access to currently updated sources of existing data, which were then verified and processed to obtain a unified form of data from both countries, which allowed for their comparison. This allowed for a complete diagnosis of the current state of national parks, with the indication of differences in both compared systems. The image obtained in this way was analysed to evaluate both systems' potential. The main focus was on the basic problems that emerged during the analysis, thus assessing the effectiveness of both countries' formal and legal solutions.

Although it would seem that comparing the ways in which national parks function on both sides of the border should not pose any significant problems, the truth is somewhat more complicated. An attempt to analyse the nature protection systems in both countries leads to an unavoidable conclusion that the discrepancy concerns the very definition of a national park and its location in the system of area forms of nature protection. While in Poland, the national park is the highest form of nature protection, in Ukraine, there are two more categories of protected areas above the national nature parks (called National Nature Parks), namely the preserves and the preserves of the biosphere. These forms do not function in Polish legislation (equivalents of biosphere predictors in Poland are biosphere reserves, which, however, are not in any way embedded in the Act on Nature Protection). The difference between the different categories of Ukrainian protected areas is important for further considerations.

Nature Preserves protect areas with the highest natural values, which are important from the point of view of nature protection on the national scale. They are created not only to preserve in their natural state unique ecosystems in Ukraine but also to protect typical habitats characteristic of a particular type of landscape. These areas are under strict nature protection and are completely excluded from any commercial use. The main purpose of the existence of the preserves is to protect all the natural resources in their area, 
as well as to conduct scientific research and monitoring. The data collected in the preserves (which are a kind of "reference areas" for the rest of the protected areas) is the basis for forming recommendations for nature protection on a national scale. If the land is transferred to the Ministry of Environmental Protection or the National Academy of Sciences of Ukraine, such areas are referred to as nature preserves.

Another category is natural national parks, which constitute the third category in the territorial forms of nature protection system in Ukraine. They also include naturally valuable areas, and, similarly to the preserves, they are excluded from commercial use. However, their goals include - apart from nature protection and conducting scientific research - protection of cultural and historical resources, making the protected areas accessible for tourism and recreation and conducting activities in the field of ecological education. Protected areas in the form of national nature parks may include areas that are not only owned by the state but also by other owners.

The above comparison clearly indicates that in terms of the goals of their existence, tasks, and ownership structure, the natural national parks of Ukraine are the equivalents of Polish national parks, and this analysis will focus on those areas. However, one should not forget that despite the fact that there are no nature preserves in Poland, many areas under strict protection in Polish national parks show equally high natural value.

\section{Results}

The basic legal Act regulating the issues of nature protection in Poland is the Act of April 16, 2004, on Nature Protection (Journal of Laws of 2020, item 1378). It defines what nature protection really is, understanding it as the preservation, sustainable use and renewal of resources, formations and components of nature (Article 2 of the Act of April 16, 2004, on Nature Conservation). The presented Act sets broad objectives for nature protection, which include maintaining ecological processes and the stability of ecosystems, maintaining biological diversity, preserving geological and paleontological heritage, ensuring continuous existence of plant, animal and fungi species, together with their habitats, by maintaining or restoring them to the proper state of protection, protecting landscape values, greenery in towns and villages and afforestation, maintaining or restoring natural habitats to the proper state of protection, as well as other resources, formations and components of nature, and also shaping proper human attitudes towards nature through education, information and promotion in the field of nature protection (Ibid.). 
Table 1. Comparison of national parks in Poland and Ukraine

\begin{tabular}{|c|c|c|c|}
\hline No. & Criteria for comparison & Polish national parks & Ukrainian national parks \\
\hline 1. & Number of units & 23 & 53 \\
\hline 2. & Total area & $\begin{array}{l}3168 \mathrm{~km}^{2} \\
\text { (1\% of the area of the country) }\end{array}$ & $\begin{array}{l}13276 \mathrm{~km}^{2} \\
(2,2 \% \text { of the area of the country)) }\end{array}$ \\
\hline 3. & The area of the smallest park & $21,46 \mathrm{~km}^{2}$ & $2316,16 \mathrm{~km}^{2}$ \\
\hline 4. & The area of the largest park & $592,23 \mathrm{~km}^{2}$ & $16,48 \mathrm{~km}^{2}$ \\
\hline 5. & $\begin{array}{l}\text { The year in which the oldest } \\
\text { park was established }\end{array}$ & 1932 & 1980 \\
\hline 6. & $\begin{array}{l}\text { The year in which the youngest } \\
\text { park was established }\end{array}$ & 2001 & 2020 \\
\hline 7. & Creating institution & $\begin{array}{l}\text { Council of Ministers (borders and } \\
\text { statute introduced by the minister } \\
\text { responsible for the environment) }\end{array}$ & $\begin{array}{l}\text { President of Ukraine (the regulations must be } \\
\text { approved by the Council of Ministers) }\end{array}$ \\
\hline \multirow[t]{3}{*}{8.} & $\begin{array}{l}\text { Supervising / managing } \\
\text { institution }\end{array}$ & $\begin{array}{l}\text { Ministry of the Climate and Environ- } \\
\text { ment }\end{array}$ & $\begin{array}{l}\text { Ministry of Environmental Protection and } \\
\text { Natural Resources of Ukraine (for most } \\
\text { of parks) }\end{array}$ \\
\hline & & & $\begin{array}{l}\text { State Agency for Forest Resources of Ukraine } \\
\text { (eight national parks) }\end{array}$ \\
\hline & & & State Administration (one national park) \\
\hline 9. & Sources of funding & $\begin{array}{l}\text { Subsidy from the state budget } \\
(33 \%) \text {, the park's own revenues } \\
(36 \%) \text {, national and international } \\
\text { special purpose funds (31\%) }\end{array}$ & $\begin{array}{l}\text { Subsidy from the state budget ( } 80-100 \%) \text {, the } \\
\text { park's own revenues (do } 20 \% \text { ), special purpose } \\
\text { funds (for nature protection), support from the } \\
\text { business and private sector, international } \\
\text { technical assistance }\end{array}$ \\
\hline 10. & $\begin{array}{l}\text { Dedicated service inside } \\
\text { the park staff }\end{array}$ & $\begin{array}{l}\text { National park service - designated } \\
\text { positions on the basis of the Nature } \\
\text { protection act and the ordinance of } \\
\text { the Minister of the Environment on } \\
\text { qualification requirements in Nps }\end{array}$ & $\begin{array}{l}\text { The State Protection Service provided by the } \\
\text { Resolution of the Council of Ministers of } \\
\text { Ukraine of July } 14,2000 \text { "About the State } \\
\text { Protection Service of the Nature Reserve Fund } \\
\text { of Ukraine" }\end{array}$ \\
\hline 11. & $\begin{array}{l}\text { NGOs associating national } \\
\text { parks / acting for the benefit } \\
\text { of national parks }\end{array}$ & $\begin{array}{l}\text { Association of the Employers } \\
\text { of Polish National Parks }\end{array}$ & Association of Protected Areas of Ukraine \\
\hline 12. & $\begin{array}{l}\text { The influence of the state } \\
\text { forests }\end{array}$ & Financial support (Forest fund) & $\begin{array}{l}\text { Influence on the creation and functioning } \\
\text { of national parks (many national parks are } \\
\text { created in the areas of state forests) }\end{array}$ \\
\hline 13. & Strategic plan & $\begin{array}{l}\text { National Park Protection Plan - } \\
\text { valid for } 20 \text { years }\end{array}$ & $\begin{array}{l}\text { Project of Organization of the Territory - park } \\
\text { development strategy ( } 10 \text { years), main activities } \\
\text { of the national park ( } 5 \text { years) }\end{array}$ \\
\hline
\end{tabular}

Source: author's work. 
The Act on Nature Protection also formulates a catalogue of forms of nature protection, which under Polish legislation are: national parks, nature reserves, landscape parks, areas of protected landscape, Natura 2000 areas, natural monuments, documentary sites, ecological grounds, natural and landscape complexes and species protection of plants, animals and fungi (Article 6 of the Act of April 16, 2004, on Nature Conservation). The position of national parks on the aforementioned statutory list is not accidental - they constitute the highest form of nature protection in the light of Polish legislation, so it is not surprising that a significant part of the whole Act on Nature Protection is devoted to them. It should also be noted that the level of complexity of the functioning of national parks in Poland makes them regulated not only by the Act on Nature Protection. Currently, entries directly related to the activities of national parks can be found in nearly 120 legal acts in the rank of an act and in almost four thousand executive acts in the rank of a regulation. Such a strong dispersion of legislation concerning national parks does not facilitate their functioning, hence the recurring idea of creating a separate legal act, which would be the Act on National Parks, gathering the majority of regulations concerning the highest form of nature protection (Pasierbek, 2020).

The existing legal conditions, issues of financing sources and the location in the spectrum of responsibilities of individual ministries and other institutions generate specific problems in the functioning of national parks in Poland and Ukraine (table 1).

\section{National parks in Polish law}

The Act mentioned above of April 16, 2004, on nature protection recognises as a national park an area distinguished by a special natural, scientific, social, cultural and educational values. The law also limits the size of the national park by defining its minimum area at $1000 \mathrm{ha}$. In this area, the whole nature and landscape values are subject to protection (Article 8 of the Act of April 16, 2004, on Nature Conservation). The Act on Nature Protection also indicates a catalogue of prohibitions that apply in the area of each national park, the purpose of which is to preserve the natural values protected there (Article 15 of the Act of April 16, 2004, on Nature Conservation).

The purpose of the national park's existence is not only to preserve biodiversity, resources, formations and components of inanimate nature, and landscape values, but also to restore the proper condition of nature's resources and components, as well as to reconstruct deformed natural habitats, plant habitats, animal habitats, or fungi habitats (Article 8 of the Act of April 16, 2004, on Nature Conservation). In practice, it means that areas 
where man has transformed nature, but there is a real chance to restore a high level of wildness in this area, can be included in the national park. This definition justifies also performing active protection activities in national parks, aiming to achieve statutory goals of the highest form of nature protection in Poland.

The objectives defined in this way are reflected in the legislator's tasks set before the national parks. These include:

- carrying out protection activities in the ecosystems of the national park, aiming at realising the above mentioned statutory goals of the existence of national parks,

- making the area of a national park available in accordance with the principles specified in the protection plan or protection tasks and the resolutions of the director of the national park,

- carrying out activities related to nature education (Article $8 \mathrm{~b}$ of the Act of April 16, 2004, on Nature Conservation).

The issue of making the national park accessible, included in the second task, is further specified in the content of the Act on Nature Protection, specifically in part concerning the National Park Service. It states that the tasks of the National Park Service include making the area of the park available for scientific, educational, recreational and sporting purposes. It is also worth noting that the above mentioned three tasks set by the national parks are not a closed catalogue, which is evidenced by the fact that the list mentioned above is preceded by the phrase "in particular". However, it should be remembered that the tasks set for national parks, especially making the area of the park available to the public, cannot stand in opposition to the fundamental purpose of this form of nature protection, which is to preserve the values of living and inanimate nature (Article 12 of the Act of April 16, 2004, on Nature Conservation).

From the administrative point of view, a national park is a state legal entity in the understanding of article 9, point 14 of the Act of August 27, 2009, on public finances (Article 8a of the Act of April 16, 2004, on Nature Conservation). It means that it belongs to the public finance sector; it is established by the Act, based on the Act or in the execution of the Act by the government administration body to realise public tasks (Article 3 of the Law of December 16,2016 , on the principles of state property management).

The role of supervision over 23 independent entities, which Polish national parks are, is assigned by the Nature Protection Act to the minister in charge of the environment (currently, from October 6, 2020, it is the Minister of Climate and Environment). This supervision includes, in particular, the approval of annual material tasks resulting from the protection plan or protective tasks, the control of the functioning of national parks, the control of 
the performance of economic activities by national parks, the control of the implementation of national parks' tasks, the control of the implementation of national parks' financial plans and the control of the activities of the national park director undertaken as a nature protection authority (Article 9 of the Act of April 16, 2004, on Nature Conservation). The minister in charge of the environment also grants the national park a statute defining, among others, the internal organisation of the national park in order to ensure efficient functioning of the national park and proper execution of its tasks (Article $8 \mathrm{f}$ of the Act of April 16, 2004, on Nature Conservation).

The individual status of a state legal person gives each of the Polish national parks considerable independence and freedom. It is clearly visible in organisational matters and in managing the institution. Each of the parks takes decisions independently, without the need for consultation or agreement with other parks, which means that in similar cases, the decisions of individual parks may be divergent. The organisational structures of national parks are also difficult to compare - although the positions in the National Park Service are defined in the Act, and the qualification requirements for their occupation are specified in the appropriate regulation (Regulation of the Minister of the Environment on positions and qualification requirements to be met by employees working on particular positions in the National Park Service of April 28 2005) the internal division of the park into organisational units is established separately in each national park. The director of each Polish national park independently represents the park externally and takes decisions regarding commitments made by the given national park. This refers not only to obligations in the form of employment contracts, civil-law contracts or contracting goods and services, but also to undertaking cooperation, including international ones (many Polish national parks have signed appropriate agreements with parks, institutions or non-governmental organisations dealing with nature protection from different countries). There are also different management standards, particularly national parks, which do not have to be unified.

Although the specification of each of the Polish national parks is different, what undoubtedly links them is the enormous natural value of those areas. Therefore, to further strengthen the protection of national parks against the negative impact of human activity, a buffer zone, called the buffer zone of the park, is delimited on the areas bordering the national park (Article 11 of the Act of April 16, 2004, on Nature Conservation).

The basic strategic document regulating the functioning of a national park in Poland is the protection plan. It is assumed that it should be created within 5 years from the date of establishing the national park (Article 18 of 
the Act of April 16, 2004, on Nature Conservation); however, currently, the majority of national parks are still at the stage of creating the protection plan.

A project of a protection plan is prepared by the director of a national park, ensuring the possibility of public participation in its creation. It also requires an opinion of local boards of communes. Such a prepared project is submitted to the minister in charge of the environment, who establishes the protection plan for the national park by decree or refuses to establish it if the draft plan contradicts the objectives of nature protection (Article 19 of the Act of April 16, 2004, on Nature Conservation).

\section{Sources of National Park funding in Poland}

The separate legal personality of each national park also means that each of them runs its own financial management. Legislators have made it possible for national parks to perform the economic activity, restricting that this activity cannot conflict with the Act's regulations on nature protection (Article $8 \mathrm{~b}$ of the Act of April 16, 2004, on Nature Conservation). In other words, national parks have the right to generate their own revenue, but this activity must not conflict with the primary goal of environmental protection.

Carrying out independent financial management, Polish National Parks cover, from their funds and revenues, the expenses connected with realisation of tasks defined in the Act, including National Park Service tasks, as well as other activity costs. This is done based on an annual financial plan that is the basis of park financial management, including, among others, income from conducted activities, subsidies (including those from the state budget), costs and funds for property expenses (Article $8 \mathrm{~g}$ of the Act of April 16, 2004, on Nature Conservation).

The legislator has also identified potential sources of income for national parks, which can be summarised into three basic categories:

1. Subsidies from external sources, including the state budget, domestic and foreign purpose funds (EU and others);

2. Earnings from the statutory activities of the park, including income from the sale of products obtained through the implementation of tasks resulting from the protection plan or protective tasks, income from fees collected in connection with park educational activities and from the sale of educational, scientific and information materials, income from entrance fees to the park, as well as income from the rental of premises;

3. Other sources of park income not covered above, such as donations, inheritances, or generated by conservation projects (Pawlusiński, 2019). It should be mentioned that revenues from certain sources can only be used to perform the first of the park's statutory tasks, i.e. to carry out protec- 
tive work in national park ecosystems (Article 8h of the Act of April 16, 2004, on Nature Conservation).

Analysing the current financial situation of Polish national parks, it should be noted that, although the income structure in particular national parks may significantly differ from one another, it is possible to make some generalisations pointing to the main regularity in the financing of national parks. Although included in the public finance sector, Polish national parks cover on average about $1 / 3$ of their costs from subsidies from the state budget (Raj, 2019). Another 36\% is the park's own income, which, depending on the specifics, can be income from fees for access to the park, income from leasing land or from the sale of products derived from protective operations (e.g. timber from sanitary cuts). About $30 \%$ of parks' revenues are grants from purpose funds, both national (NFEP\&WM, VEPF, Forest Fund) and international (EU, EEA, GEF and others), (Babczuk and Kachniarz, 2015). The share of grants has been increasing in recent years, especially due to the support given to national parks by the Forest Fund and the implementation of numerous infrastructure projects financed by the European Union.

A rarely used but allowed by the Act, national parks financing are also loans and credits that parks can take for their activities. The Act strictly defines such activity - it requires the approval of the minister in charge of the environment in agreement with the minister in charge of finance, and the amount of incurred liabilities cannot exceed $60 \%$ of the amounts included in the financial plan of income or $60 \%$ of costs (Art. 8h (3) of the Act of April 16, 2004, on Nature Conservation).

The complicated financial structure of Polish national parks does not facilitate the management of these units. This is particularly visible from the level of cooperation between national parks - financial flows between parks are practically impossible, which, in principle, does not allow parks in a more difficult financial situation or facing large investments to be supported by parks that have significant revenues. This makes the division into richer and poorer parks more critical, while it is worth noting that, for example, the tourist attractiveness, and therefore the potential to generate income in individual parks, can be very different. The lack of a common financial policy makes it extremely difficult to coordinate the tasks performed by national parks, as well as strategic planning of activities in national parks at the national level. 


\section{Organisation of national parks in Ukraine}

Considering the national importance of national nature parks, their activities are regulated by national laws and other regulations, mainly the Ukrainian law "On Nature Reserves". In particular, the problems of the functioning of national nature parks are revealed in Chapter 3. This chapter explains the status, tasks and functional zoning of national parks but does not reveal the features of their functioning that caused the need for another lower level legislation. There is no separate law on the operation of national nature parks to date.

Among other laws related to the development of environmental protection is the Law of Ukraine "On the Ecological Network of Ukraine". National nature parks are defined as elements of the national ecological network in Ukraine.

Certain directions of the functioning of national parks are determined by various resolutions of the Cabinet of Ministers of Ukraine. In particular, the issue of compliance with the ecological regime is regulated by the Resolution of the Cabinet of Ministers of Ukraine "On approval of the fee for calculation of the amount of damage caused by violation of the regulations on nature reserves" (№ 541 z 24.07. 2013).

The park activities are described in detail in the regulations approved by the competent ministry. The most strategic regulations for the activities of the national nature park are the "Regulations on the project of organisation of the national nature park, protection, reproduction and recreational use of its natural complexes and objects", enacted in 2005 national park. The issue of individual national park territories is regulated by various regulations, including: "Regulations on scientific and scientific-technical activities of nature and biosphere reserves and national parks" (approved by the Order of the Ministry of Ecology and Natural Resources of Ukraine № 414 of 29.10. 2015); "Regulations on ecological education of nature reserves" (approved by the Order of the Ministry of Ecology and Natural Resources of Ukraine № 399 of 26.10.2015); "Regulations on recreational activities on the territories and fund objects of nature reserve of Ukraine" (approved by the Order of the Ministry of Environmental Protection of Ukraine № 333 of 22.06.2009). There are also many guidelines for issuing permits and setting restrictions for special use of natural resources in protected areas.

It should be noted that the creation of national parks is carried out by publishing a decree of the President of Ukraine "On the creation of a national nature park". Then, the Cabinet of Ministers of Ukraine must approve the newly created national park regulations. 
The Ministry of Environmental Protection and Natural Resources of Ukraine is responsible for most of Ukraine's national parks. Eight national parks (Kreminski Lisy, Male Polesya) are under the jurisdiction of the State Agency for Forest Resources of Ukraine - the central executive body of Ukraine for breeding forest, hunting and game dogs. Azov-Sivaska National Nature Park is legally subordinated to the State Administration - a special state body for logistic, social and other support of the President of Ukraine, the Verkhovna Rada, the Council of Ministers, the National Security and Defense Council and others government agencies, all international diplomatic missions in the country.

Each national nature park maintains accounting, operational accounting, compiles periodic, annual, financial and statistical reports and submits them in the prescribed manner. The director and the chief accountant of the park are personally responsible for the organisation and maintenance of accounting and operational accounting, its accuracy, maintenance of periodic, annual, financial, statistical and other reporting, as well as for the preservation of relevant documentation. The park reports on its activities, in particular, to the Ministry of Environmental Protection and Natural Resources of Ukraine and the relevant state executive authorities in the manner and within the time limits specified by the law.

The Chronicle of Nature is one of the main forms of reporting in national nature parks. The major form of generalisation of the results of scientific research in reserves and national nature parks is the Chronicle of Nature which is conducted in accordance with approved manuals, instructions, and recommendations. The Chronicle of Nature provides basic data on nature's calendar, physical and geographical conditions, flora and fauna, anthropogenic impact on nature reserves. A separate section also describes research on other topics. The Chronicle of Nature also provides appendices. Chronicle of Nature - is a research project, which is constantly conducted, and its results are published annually in separate volumes. In addition to the natural history record, national parks annually prepare "Information on the results of the scientific research activities of the park".

The structural connection between the national nature parks of Ukraine is provided by the Resolution of the Cabinet of Ministers of Ukraine of July 14, 2000, "About the State Protection Service of the Nature Reserve Fund of Ukraine". The State Protection Service of the Nature Reserve Fund of Ukraine provides protection and preservation of nature reserves, biosphere reserves, national nature parks, botanical gardens, dendrological parks, zoological parks, parks-monuments of landscape art and regional landscape parks. 
The State Protection Service in accordance with the tasks assigned to it:

- protects natural complexes of nature reserves, biosphere reserves, national nature parks, botanical gardens, dendrological parks, zoological parks, parks-monuments of landscape art and regional landscape parks;

- protects wildlife and their habitats on the lands and facilities of the wildlife sanctuary fund;

- ensures the use of natural resources;

- provides compliance with the requirements for visiting the lands and facilities of the nature reserve fund;

- prevents damage to forest plantations due to illegal logging;

- takes measures to prevent the occurrence, spread and fight fires and other emergencies;

- informs relevant state authorities of emergencies;

- ensures the implementation of measures to prevent and protect natural complexes from pests and diseases on reserve fund lands and facilities;

- maintains borders and security signs, information signs, quarter and field poles, as well as fire-fighting structures in good condition;

- ensures compliance with the regime of the territories and facilities of the reserve fund, including compliance with the requirements of the projects of organisation of the territories and facilities or the projects of maintenance and restoration of the facilities of the reserve fund throughout its territory;

- explains the need to preserve particularly valuable natural complexes and facilities.

It should be noted that the representatives of the State Protection Service are the direct employees of separate national parks. Within the park, the Service includes the director, chief naturalist and employees of the department of state protection of the nature reserve fund.

Among the national NGOs that directly specialise in the management of protected areas is the Association of Protected Areas of Ukraine - an all-Ukrainian public organisation created to support the protected areas of Ukraine, unifying them into one system, improving the management of protected areas of Ukraine nature reserves and environmental education. The association was established with the support of a collaborative project of the United Nations Development Program in Ukraine and the Global Environment Facility: "Strengthening the management and financial sustainability of the national system of protected areas in Ukraine". The activities of the association cover the entire territory of Ukraine. In particular, the collective members of the association are the national nature parks: Halytsky, Ichnyanskyi, Sviati Hory, Velykyi Luh, Hutsulshchyna, Skolivsky Beskydy and others. 
When it comes to the internal structure of national nature parks, it is mostly consistent for all national nature parks. It comprises different departments - state nature reserve protection, economic, scientific, recreational and tourism.

Besides the relevant ministry, the State Forest Resources Agency of Ukraine influences the functioning and creation of national nature parks. Finally, mainly nature reserves are created on its territories. In particular, $16.6 \%$ of forests under the management of the State Forest Resources Agency of Ukraine are protected. Almost in all regions, forest reserves are higher than national ones. The forest plots belonging to the Forest Fund of Ukraine are 10.4 million hectares, including 9.6 million hectares covered with forest vegetation. Of this, 7.6 million hectares $(73 \%)$ are under the management of the State Forest Resources Agency of Ukraine. The reserve forests of the State Forest Resources Agency of Ukraine occupy one third (33\%) of the state reserve fund, and the forest coverage of the territory of Ukraine - 15.9\%. In Ukraine, logging in the main use is already prohibited in $46.9 \%$ of forested areas.

In the forests of the State Forest Resources Agency of Ukraine, more than 3,300 nature reserve fund sites and facilities with a total area of 1.3 million ha have been created. In addition, the State Agency for Forest Resources of Ukraine in recent years approved proposed decrees of the President of Ukraine on the establishment, among others by the forests of the State Agency for Forest Resources of Ukraine, of national nature parks - Kamyanskaya Sich, Nobelskiy, Bojkovshchyna, Kreminskiy Lisy with a total area of 32.4 thousand ha, as well as proposals of decrees of the President of Ukraine on the change of borders (expansion) of national nature parks - Oleshkivski Pisky, Dniester Canyon, Uzhansky National Nature Park, etc. Today, forest areas are the main source of increasing the state reserve fund. In 2020, two national parks were created in the forests of the State Forest Resources Agency of Ukraine: Kuyalnytsky and Pushcha Radzivila.

According to the legislation of Ukraine, the sources of financing of national nature parks can be general funds of the state budget, environmental protection funds (environmental funds), private funds of business entities, international technical assistance. The main part of the financing of national nature parks falls on state subsidies (state budget fund, environmental fund). Its share varies from 80 to $100 \%$, depending on the park's activities and the specifics of its location. Income from economic activity varies from 0 to $20 \%$. The smallest part is international technical assistance, which is intermittent and fragmentary in nature. The analysis of financial indicators of the Shatsky Landscape Park (as one of the oldest and recreationally developed parks in Ukraine) indicates the following structure of income: $82 \%$ - income from the 
state fund; $17.9 \%$ - income from provided services and economic activity; $0.1 \%$ - donations. In national parks it is necessary to pay more attention to the possibilities of obtaining international financial assistance, as well as to increase the possibility of obtaining additional funds through the providing of paid services.

According to Chapters 47 and 48 of the Ukrainian Law "On the Nature Reserve Fund", national nature parks may receive income from their statutory activities and create special ecological funds, which are supplemented by fees for violations of environmental regulations.

Providing paid services by national natural parks is regulated by the Resolution of the Cabinet of Ministers of Ukraine "About the approval of the list of paid services that may be provided by budgetary institutions of the nature reserve fund" (No. 1913 of 28.12. 2000). According to this regulation, national nature parks may carry out 19 different types of economic activities: leisure and tourist services; photography and video services; accommodation, food and transportation of tourists; veterinary services; sale of livestock and plant products; organisation of ceremonial events; location of commercial sites; sale of timber and wood products, etc. Within the list provided, park administrators may organise various business enterprises.

According to the "Regulations on the Project of Organization of National Nature Park, Protection, Reproduction and Recreational Use of its Natural Assemblages and Objects", each national nature park must have a Project of Organization of the Territory formulated and approved. It predicts the strategic plan of territory development for 10 years and main activities for five years. The project is prepared on the basis of regulations on dedicated parks approved by the Cabinet of Ministers of Ukraine.

The main tasks of the Territorial Organization Project are:

- to define the park development strategy for 10 years;

- to carry out a scientifically justified functional zoning of the park area and to establish a territorially differentiated regime of protection;

- to determine in accordance with the strategy and then implement by it concrete efficient actions for the development of the park, conservation, reproduction and leisure use of its natural complexes and facilities for five years.

In general, the project includes the following main components: park description, identifying priorities and problems, a ten-year strategy for park development, a five-year action plan, measures and resources, applications (cartographic materials, documents, functional zones).

The functioning of national nature parks in Ukraine does not contradict the development of communities. The borders of national parks include the settlements and facilities operating there. Therefore, conflicts between park 
management are not excluded, which is connected with different visions of land development, but such conflicts are isolated. They are mostly related to illegal activities in the park: fishing, hunting, logging, etc. It should be noted that, in general, the public recognises the significance of a high-ranking environmental site's operation, and the escalation of environmental problems encourages the emergence of environmental awareness among the population.

\section{Conclusions}

Analysing the quality of management in national parks, one can clearly see the influence of the organisation of the nature conservation system itself, both in Poland and in Ukraine. The basic problem, which is already drawn at a cursory glance, is the lack of clear organisational links between protected areas. Individual national parks in Ukraine are under the supervision of different ministries or state forests, which definitely does not facilitate the coordination of activities undertaken in these areas. In Poland, all national parks are supervised by the minister responsible for the environment. However, it does not mean that we can talk about common management of protected areas in this case. The separate legal entity of each of the national parks makes them managed in a completely independent way. Internal organisational structure, resulting from the statute given by the minister, can be even similar, but its reflection in the functionality belongs to the specifics of each national park. Each park adjusts the structure individually to its needs, which makes, even at this level, any comparison between parks extremely difficult.

A similar situation occurs in the case of financial management. Considerable autonomy in decision-making in this respect causes particular national parks to differ not only in the structure of income and costs but also in the plan of accounts or in the financial and accounting programs used. This makes it almost impossible to summarise all parks' economic activities, hindering collective reports covering the units supervised by a particular minister. The individual approach to each national park also leads to discrepancies in tax issues. Although it would seem that taxes should affect every public institution in the country in the same way, it happens that in detailed issues, tax regulations are subject to the interpretation of regional branches of National Tax Information. These interpretations are binding in a given case and apply only to the requesting institution. This means that such a fundamental issue as the possibility to deduct tax on goods and services in different national parks may be different because they are subject to different locally competent tax authorities. 
Conducting economically stable activities is one of the key conditions for realising the idea of nature protection. The fragmentation of the sources of income, and especially the insufficient level of subsidies from the state budget, are another problem influencing the management and decision-making processes. National parks are units, by definition, intended to protect natural resources, and this activity should be their priority. Meanwhile, the lack of financing from the state budget for the basic needs of the parks, such as conducting protection activities or the costs of employing staff with appropriate competencies, makes the administration of protected areas look for additional sources of funding. It is not a problem if additional sources of income are national or international purpose funds dedicated to nature protection, but it is definitely not enough in many cases. It is then necessary to work out the income on their own, without which the functioning of the national park will be questioned. The Act states that conducting profit-making activity by the park cannot contradict the primary goal of its existence, which is nature protection. However, it is to be feared that the need to find funds for remuneration of employees or other liabilities due may lead to bending, if not an outright violation of this principle. It may result, for example, in exceeding the tourist capacity of the area or making the national park into an object that does not differ much from a commercial forest.

Making independent decisions by particular National Park directors also concerns the issues related to nature protection and making the national park area accessible. Lack of necessity to agree on a common position in matters referring, for example, to tourist or leisure activities in the area of national parks causes those decisions made by particular directors may not only be divergent but often even mutually exclusive. This greatly weakens the message of nature protection - tourists visiting national parks may do things in some parks that are forbidden in others. This immediately raises questions about the substantive justification of rules in national parks and the arbitrary nature of decisions made by those who manage them. This usually concerns issues with strong social connotations, resulting from clearly defined expectations of visitors to national parks, such as the problem of bringing dogs into the area of a national park, moving around the park after dark, or - in the case of mountain parks - the use of ski-touring equipment.

Furthermore, the quality of management in national parks is affected by the previously described interdisciplinary nature of national park activities, resulting in a huge dispersion of normative acts regarding the functioning of this category of protected areas. It is not difficult to guess that it does not increase the quality of management in protected areas - the necessity to translate hundreds of legal acts in the rank of acts and regulations into management and administrative practice is time-consuming and requires expert 
knowledge of the law. There is also an increased risk of making a mistake resulting from misinterpretation of some regulations. It is even greater because each national park in Poland does it independently - in many cases, there are no top-down guidelines even on basic issues.

Another issue affecting the quality of management of protected areas is weakening representation at the central level. Because there is no single organisational unit representing the interests of all national parks, whose voice would be much more distinct than the voices of individual national parks, the needs of national parks are perceived as local, unimportant from a national perspective, and thus marginalised. It may also lead to "fratricidal" competition between national parks - the richer, more popular and widely known parks will have much more influence on decisions concerning the whole nature protection system than their "smaller siblings".

However, the independence of national parks, resulting from the organisation of the nature protection system, also has its undeniable good sides, which improve the quality of the management process of these areas. The possibility of individual decision-making contributes to a significant acceleration of the decision process, which takes place bypassing central institutions. It also reflects more fully the specificity of a given national park, to which the central bodies may not pay due to attention. The separate legal personality of each protected area also contributes to establishing the national park in the region, building an appropriate social environment necessary for the proper functioning of nature protection. It allows for direct contact between the local community representatives, and especially of the local self-government at various levels, with the decision-makers in national parks, which, with significant centralisation of the nature protection system, could be impossible and certainly would be much more difficult.

It is extremely difficult to compare the organisation of the nature protection system in different countries. They function in different legal, administrative and economic conditions, in a different system of values and in a different social environment. However, it is certainly worth investigating various models of institutional nature protection, and especially their influence on the quality of the management process itself - both the area, understood as a form of nature protection, and the institution of the national park, considered as a workplace or a public administration body. The undeniable connection between the organisation of nature protection system and decision-making efficiency and effectiveness should be a subject of deeper research aiming at working out a way to increase the quality of protected areas administration.

Coordination of activities carried out by national parks, which could occur at the central level, seems to be a remedy for the problems presented 
in this article. The potential creation of a new unit, whose decisions would be reflected in the functioning of national parks, or the voluntary agreement of park directors to transfer some of the competencies to an organisation that would coordinate some of the activities undertaken by all national parks, are only two of the possible ways of implementing this type of assumption. However, it requires extensive statutory changes that should lead to a single law that would normalise most national parks' functioning areas.

A mindset change at the administration level of the national parks themselves is also necessary in this regard. Ceding part of the powers to an external entity may give the impression of losing sovereignty, which never receives clear support. It is accompanied by the fear of excessive centralisation and, consequently, politicisation of the natural protection system. Building trust in such a structure certainly requires time and calm - nature protection should function stably, without unnecessary pressure, and decisions should be based on a strong factual foundation.

The above considerations lead to the conclusion that the present nature protection systems in relation to national parks in Poland and in Ukraine are waiting for changes that will improve the functioning of national parks and thus will raise the quality of the management process not only at the organisational level but also in terms of protection and management of natural components. Furthermore, reasonable modifications of statutory and organisational foundations of territorial nature protection will allow national parks to respond to present-day Central European nature challenges.

\section{The contribution of the authors}

Bezruchko Lyubomir - validation, investigation, writing - original draft preparation, writing - review and editing (20\%)

Pasierbek Tomasz - conceptualisation, methodology, investigation, writing - original draft preparation, writing - review and editing, supervision (40\%)

Juraj Rakos - validation, formal analysis, writing - review and editing, supervision $(20 \%)$

Zhuk Yuriy - validation, investigation, writing - original draft preparation (20\%)

\section{References}

Act of April 162004 on Nature Conservation (Journal of Laws of 2004, No. 92, item 880).

Act of August 272009 on public finance (Journal of Laws of 2009, No. 157, item 1240).

Act of December 162016 on the principles of state property management (Journal of Laws of 2016, item 2259). 
Babczuk, A. Kachniarz, M., 2015. Polskie parki narodowe - ujęcie instytucjonalne. In Studia i Prace Wydziału Nauk Ekonomicznych i Zarządzania 40/2, 203-213, https://doi.org/10.18276/sip.2015.40/2-16.

Mika, M., Pawlusiński, R., Zawilińska, B. 2015. Park narodowy a gospodarka lokalna. Model relacji ekonomicznych na przykładzie Babiogórskiego Parku Narodowego. Instytut Geografii i Gospodarki Przestrzennej Uniwersytetu Jagiellońskiego w Krakowie, Kraków.

Ordinance of the Minister of Environment of July 222019 on establishing a protection plan for the Babia Góra National Park (Journal of Laws of 2019, item 1699).

Pasierbek, T. 2020. Projektowane rozwiązania prawne dla parków narodowych w ocenie pracowników. In: Nocoń, M., Pasierbek, T., Raj, A., Walas, B. (Eds.), Społeczno-ekonomiczne i prawne aspekty zrównoważonego zarządzania Parkami Narodowymi. Wyższa Szkoła Turystyki i Ekologii w Suchej Beskidzkiej, Sucha Beskidzka, 77-101.

Pawlusiński, R. 2019. Finansowe aspekty funkcjonowania parków narodowych. In: Nocoń, M., Pasierbek, T., Sobczuk, J., Walas, B. (Eds.), Parki narodowe i otoczenie społeczno-gospodarcze: skazani na dialog: monografia naukowa. Wyższa Szkoła Turystki i Ekologii w Suchej Beskidzkiej, Sucha Beskidzka, 25-47.

Raj, A., 2019. Zarządzanie parkami narodowymi w Polsce - stan obecny i kierunki pożądanych zmian. In: Nocoń, M., Pasierbek, T., Sobczuk, J., Walas, B. (Eds.), Parki narodowe i otoczenie społeczno-gospodarcze: skazani na dialog: monografia naukowa. Wyższa Szkoła Turystki i Ekologii w Suchej Beskidzkiej, Sucha Beskidzka 9-24.

Regulation of the Minister of the Environment of April 282005 on positions and qualification requirements to be met by employees working on particular positions in the National Park Service (Journal of Laws of 2016, No. 89, item 753). 